\title{
Proceedings
}

\section{Design, Synthesis and Antimicrobial Evaluation of New Norfloxacin-Naphthoquinone Hybrid Molecules ${ }^{\dagger}$}

\author{
Andrea Defant 1,2, , Alessandro Vozza ${ }^{2}$ and Ines Mancini 1,* \\ 1 Laboratory of Bioorganic Chemistry, Department of Physics, University of Trento, via Sommarive 14, \\ 38123 Trento, Italy \\ 2 Istituto Tecnico Tecnologico Buonarroti, via Brigata Acqui, 15, 38122 Trento, Italy; \\ alessandro.vozza@studenti.unitn.it \\ * Correspondence: andrea.defant@unitn.it (A.D.); ines.mancini@unitn.it (I.M.) \\ + Presented at the 23rd International Electronic Conference on Synthetic Organic Chemistry, 15 November- \\ 15 December 2019; Available online: https://ecsoc-23.sciforum.net/.
}

Published: 14 November 2019

\begin{abstract}
Although the wide arsenal of drugs available to treat bacterial infections, emerging drugresistant bacterial pathogens have recently highlighted an urgent need to find new more effective and less toxic therapeutic agents. Fluoroquinolones, including norfloxacin, are antibiotics showing a concentration-dependent bactericidal capacity due to the activity inhibition of DNA-gyrase and topoisomerase IV, which are enzymes essential for bacterial DNA replication. Naphthoquinones are secondary metabolites showing different biological activities, including cytotoxic, antibacterial and antifungal effects. In particular, the efficacy of natural and synthetic 1,4-naphthoquinone derivatives is likely due to their oxidizing/reducing capability, through which they destroy cellular targets as nucleic acids. Hybrid molecules are produced combining structural features of two or more bioactive compounds, in order to obtain new therapeutic agents able, not only to reduce undesirable side effects of the parent drugs, but also to inhibit more biological targets, hopefully with a better therapeutic property than the administration of combined single-target drugs. With the aim to apply this strategy in the study of new potential antimicrobial agents, we have synthesized four hybrid molecules by the reaction of norfloxacin with suitable quinones and their activities have been evaluated against both bacteria and fungi, in comparison with synthetic precursors. The experimental data are supported by docking calculations on S. aureus DNA-gyrase, discussing the interactions involved for each hybrid molecule, in comparison with norfloxacin and the original ligand moxifloxacin.
\end{abstract}

Keywords: antibiotic; fluoroquinolone; naphtoquinone; hybrid molecules; nucleophilic substitution; Kirby-Bauer test

\section{Introduction}

In recent rational design of new drugs, molecular hybridization is a successful approach using scaffolds present in single therapeutically active agents, connected together in a new single structure by covalent bonds. The aim of this strategy is to obtain new molecules able to reduce undesirable side effects of the parent drugs, with the advantage of inhibiting more than one biological target simultaneously. This approach has been used in the studies of new therapeutics, including anticancer agents [1] and antibiotics [2]. Recently, both emerging pathogenic bacteria and antibiotics drugresistance have highlighted an urgent need to find new more effective and less toxic therapeutic molecules, although the wide known arsenal of drugs available to treat bacterial infections. In 
particular, the interest in hybrid antibacterial molecules is given by their potential ability to suppress drug resistance evolution better than monotherapy having a single-pharmacokinetic profile [3].

Quinolones are a class of potent antimicrobial molecules, among which fluoroquinolones including norfloxacin, moxifloxacin and several other ones. They target the two enzymes DNAgyrase and topoisomerase IV inside the bacterial cell, with the capacity to inhibit DNA replication and transcription. After the first-generation quinolones mainly effective against Gram-(-) bacteria, fluoroquinolones were introduced. They are more potent and show a broad spectrum of activities, but their use is limited by toxic effects, spontaneous mutation of targeted enzymes and an increased number of resistant pathogens. In particular, norfloxacin is used to treat both humans and animals against Gram-(+). and Gram-(-) bacteria.

Quinone, and mainly 1,4-naphthoquinone structures, are widely diffused in several structures of natural products and are often associated to a series of biological activities, including antibacterial [4], antifungal [5], antimalarial and anticancer properties, correlated to their high reactivity due to redox and acid/base behavior.

Hybrid molecules involving norfloxacin [6,7] and quinones [4,8-11] have been studied as antimicrobial agents but, to the best of our knowledge, no data have been reported so far on hybridization taking in account norfloxacin and naphtoquinone structures simultaneously. We report here on the synthesis of new hybrid norfloxacin-quinone derivatives, their in vitro antimicrobial activities and a computational analysis of the complexes with S. aureus DNA-gyrase.

\section{Results and Discussion}

Compounds 5-7 were synthesized by a nucleophilic substitution of norfloxacin (1) on the suitable quinones 2-4 $[12,13]$ in dichloromethane solution at room temperature in the presence of triethylamine (Scheme 1). The products were easily isolated with yields in the range $70-87 \%$. In the reaction of 1 with 6,7-dicholoroquinoline-5,8-quinone (4) the two regioisomers $N, N$-syn 7 a and $N, N$ anti $\mathbf{7 b}$ were obtained. Their relative abundance was established in ratio 7:3 by ${ }^{1} \mathrm{HNMR}$ analysis, where the signals $\mathrm{dd}(J=4.6,1.5 \mathrm{~Hz})$ at 8.99 and $9.03 \mathrm{ppm}$ were assigned to $\mathrm{H}-6$ " of $N, N$-syn $7 \mathbf{a}$ and $\mathrm{H}-5$ " of $N, N$-anti $7 \mathbf{b}$, respectively by data previously reported $[14,15]$.

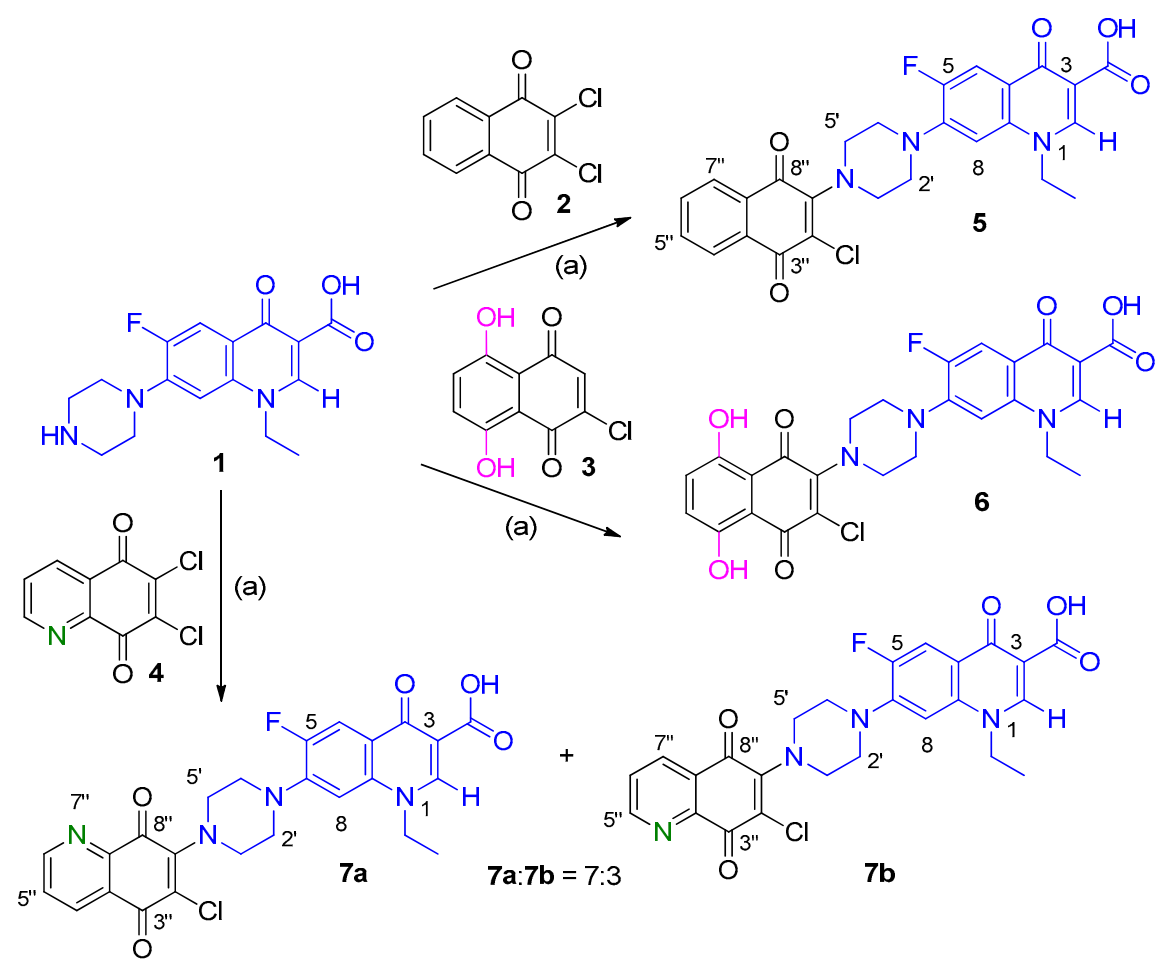

Scheme 1. Synthesis of molecules 5-7. Reagents and conditions: (a) $\mathrm{Et}_{3} \mathrm{~N}, \mathrm{CH}_{2} \mathrm{Cl}_{2}$, r.t. 48h. Arbitrary numbering is for convenience. 
Compound 5 showed a very poor solubility in all tested solvents (ethanol, dichloromethane, chloroform, dimethyl sulfoxide, diethyl ether, acetone, diethylketone). The formation of a complex using $\beta$-cyclodextrin and the use of surfactants (e.g., Triton X-100) were applied in order to increase its water solubility, but without obtaining effective results. Therefore, the compound was converted into the corresponding salt, produced in quantitative yield by treatment with sodium hydrogen carbonate. Otherwise, the use of sodium hydroxide caused degradation to 3-chlorolawsone $(=2-$ chloro-3-hydroxynaphthalene-1,4-dione) and norfloxacin. Similarly, sodium salts of 6 and $7 \mathbf{a} / 7 \mathbf{b}$ were obtained before using them in biological tests.

The synthesized compounds were evaluated for their in vitro activity against pathogenic bacteria (both Gram-(-) Staphylococcus aureus and Staphylococcus epidermidis, and Gram -(-)Escherichia coli) and against yeast Saccharomyces cerevisiae used as model for antifungal activity. The data, established as inhibition diameter $(\mathrm{mm})$ for products 5-7 in comparison with norfloxacin $(\mathbf{1})$ and the quinone precursors $\mathbf{2 - 4}$, are reported in Table 1 . Compounds $\mathbf{7 a} / \mathbf{7 b}$ resulted the most active against S. aureus, $\mathbf{5}$ was the best compound against both S. epidermidis and E.coli, all of them with values comparable to norfloxacin (1) at similar amounts. Otherwise, products 5-7 did not act as antifungal, where only the the quinones $\mathbf{2 - 4}$ displayed a moderate activity at a double concentration.

Table 1. In vitro antimicrobial activities of precursors norfloxacin (1) and quinones (2-4), and hybrid molecules 5-7 as sodium salts, expressed in inhibition diameter.

\begin{tabular}{|c|c|c|c|c|c|}
\hline \multirow[b]{2}{*}{ Compound } & \multirow[b]{2}{*}{$\begin{array}{l}\text { Quantity } \\
\text { [ } \mu \text { mol] }\end{array}$} & \multicolumn{4}{|c|}{ Inhibition Diameter [mm] } \\
\hline & & $\begin{array}{c}\text { S. aureus } \\
\text { (ATCC 6538) }\end{array}$ & $\begin{array}{l}\text { S. epidermidis } \\
\text { (ATCC 12228) }\end{array}$ & $\begin{array}{c}\text { E. coli } \\
\text { (ATCC 25922) }\end{array}$ & S. cerevisae \\
\hline 1 & 0.016 & 20.9 & 23.1 & 27.5 & 0 \\
\hline 2 & 0.044 & 8.5 & 9.6 & 7.2 & 9.9 \\
\hline 3 & 0.038 & 9.6 & 13.0 & 8.5 & 12.0 \\
\hline 4 & 0.044 & 7.7 & 8.5 & 6.7 & 10.0 \\
\hline 5 & 0.020 & 16.8 & 19.2 & 23.6 & 0 \\
\hline 6 & 0.018 & 17.4 & 9.7 & 15.4 & 0 \\
\hline $7 \mathbf{a}+7 \mathbf{b}(7: 3)$ & 0.020 & 19.3 & 11.8 & 15.1 & 0 \\
\hline
\end{tabular}

Based on the known interaction of fluoroquinolones with bacterial DNA-gyrase, a computational study was performed by molecular docking. Starting from the crystallographic X-ray structure available for DNA-gyrase in the complex with the fluoroquinolone antibiotic moxifloxacin (MFX), energy values and both type and number of interactions were evaluated for each compound $\mathbf{5}, \mathbf{6}, \mathbf{7 a}, \mathbf{7 b}$, in comparison with the original ligand MFX and Norfloxacin (1). The obtained data are reported in Figure 1. Similar energy values were calculated for all complexes. Instead the evaluation of the interaction types is interesting. In detail, the chelation of MFX with magnesium ion was no more displayed with the other ligands and molecules $5,6,7 \mathbf{a}$ and $7 \mathbf{b}$ are involved in a lower number of interaction than MFX and norfloxacin. It is notable that the hybrid molecules interact with quinone moiety. Tridimensional visual inspection of the docked superimposable ligands indicates that 6 and 7a interact in a different, close region than the quinolone drugs (Figure 2). This evidence, correlated to the major diameter inhibition against $S$. aureus of $7 \mathrm{a} / 7 \mathbf{7 b}$ and $\mathbf{6}$ in the series of the tested compounds (Table1), could be employed to overcome the quinolone resistance. 
MFX

Original ligand

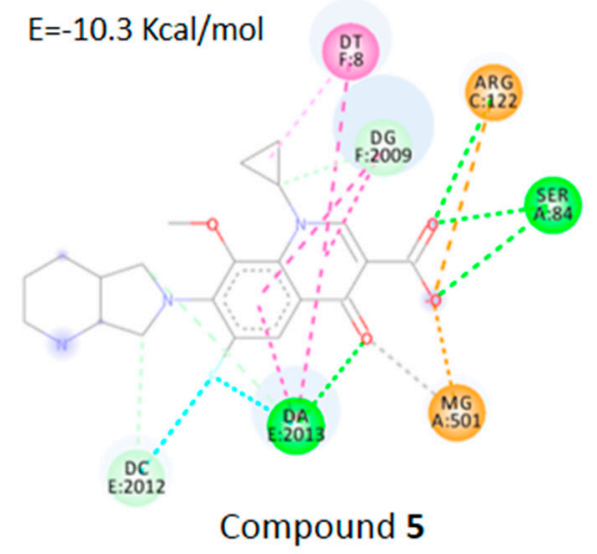

$E=-9.1 \mathrm{Kcal} / \mathrm{mol}$

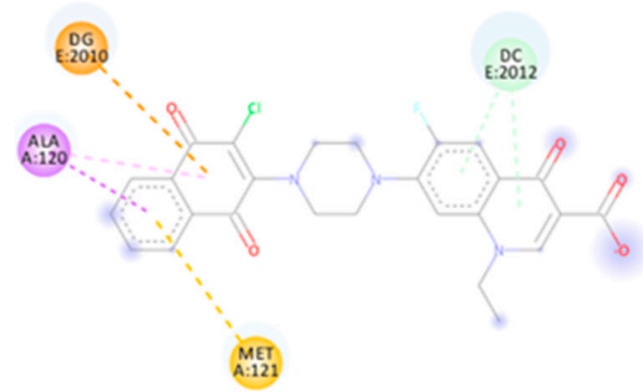

Compound 7a

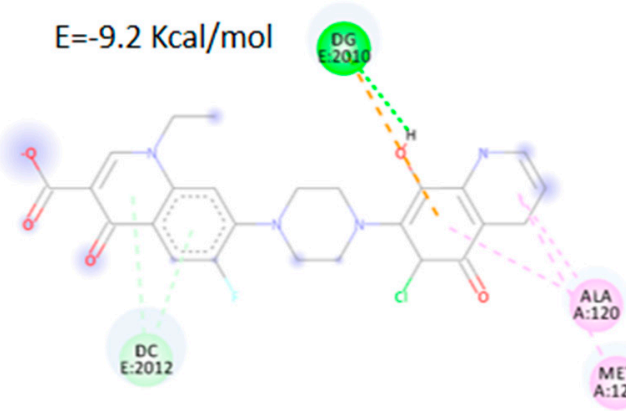

Norfloxacin (1)

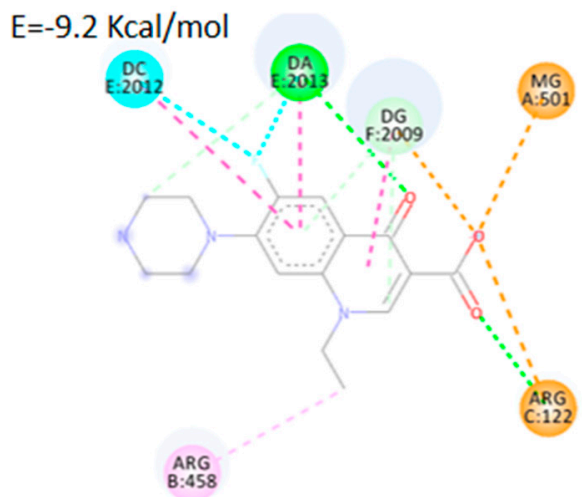

Compound 6

$E=-9.9 \mathrm{Kcal} / \mathrm{mol}$

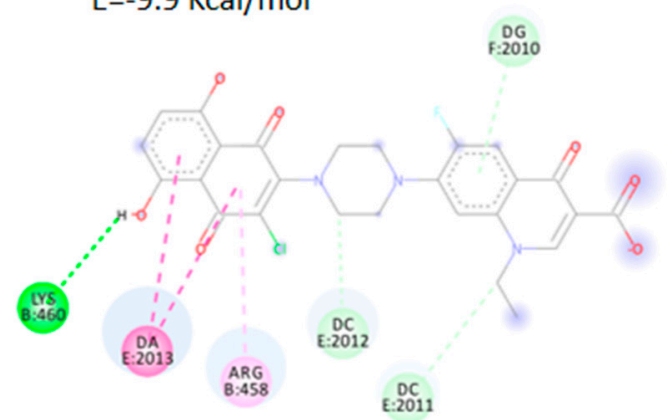

Compound 7b

$\underset{\substack{D C \\ F} 2011}{2} \mathrm{E}=-9.1 \mathrm{Kcal} / \mathrm{mol}$
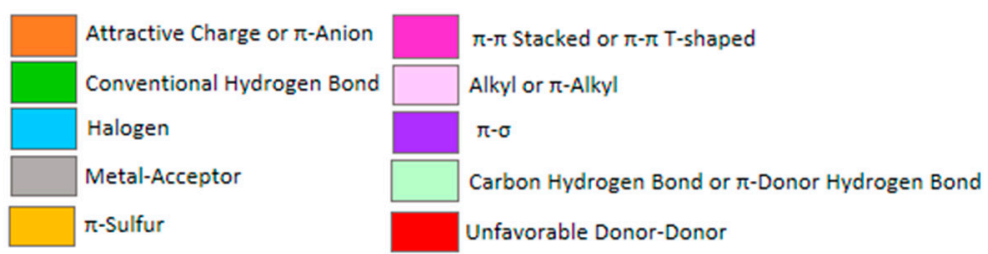

Figure 1. Data from docking calculation of the hybrid compounds $5,6,7 \mathbf{a}$ and $7 \mathbf{b}$ in the carboxylate forms with $S$. aureus DNA-gyrase (pdb code: 5CDQ), in comparison with the original ligand moxifloxacin (MFX) and norfloxacin: energy values of the corresponding complexes and 2D view of the interactions in the active site of the enzyme. 


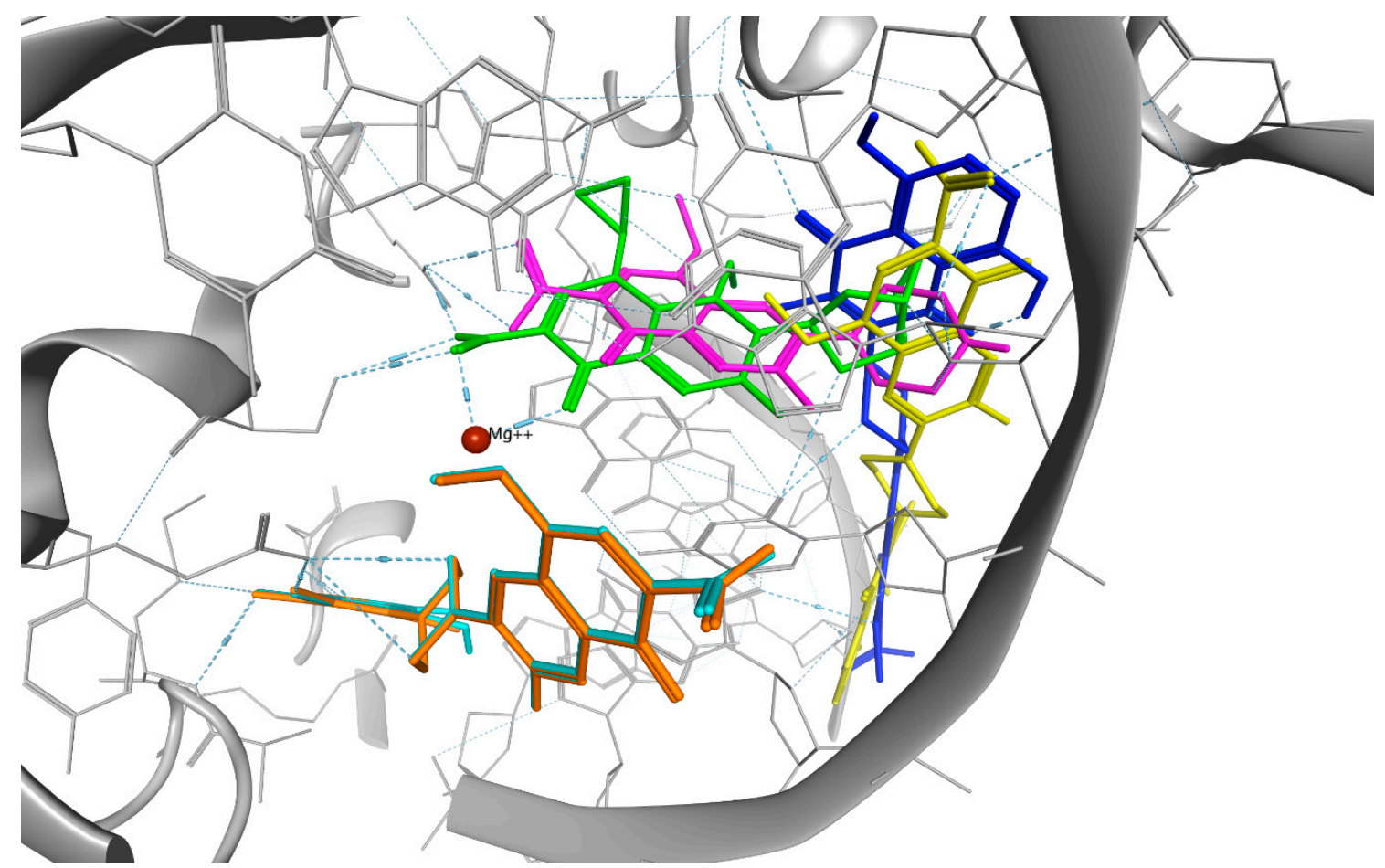

Figure 2. Data from docking calculation: $3 \mathrm{D}$ view of the interactions in the active site of $S$. aureus DNA-gyrase of the hybrid compounds in the carboxylate forms: 5 in orange, 6 in blue, 7a in cyano and $\mathbf{7 b}$ in yellow, in comparison with the original ligand MFX in green and norfloxacin (1) in magenta.

\section{Materials and Methods}

\subsection{Chemistry}

\subsubsection{General}

All reagents were purchased from Sigma Aldrich and used without further purification. 6,7Dichloroquinoline-5,8-dione was prepared according to a reported procedure [15]. The reaction yields were calculated for the products after purification. Thin layer chromatography (TLC): Merck silica gel $\mathrm{F}_{254}$ or reversed phase Merck RP-18 $\mathrm{F}_{254}$, with UV light visualization. Melting points were recorded using Thermo Scientific Nicolet 380. FT-IR spectra were acquired by a Thermo Fisher Scientific apparatus with attenuated transmitter reflection (ATR) configuration. NMR spectra were recorded on a Bruker-Avance 400 spectrometer by using a $5 \mathrm{~mm}$ BBI probe ${ }^{1} \mathrm{H}$ at $400 \mathrm{MHz}$ (relative to $\delta$ н 7.25), $\delta$ values in ppm, $J$ values in $\mathrm{Hz}$; assignments are supported by heteronuclear multiple bond correlation (HMBC) experiments. Electrospray ionization -mass spectra(ESI-MS) were recorded using a Bruker Esquire-LC spectrometer in negative ion mode by direct infusion of a methanol solution (source temperature $300{ }^{\circ} \mathrm{C}$, drying gas $\mathrm{N}_{2}, 4 \mathrm{~L} \mathrm{~min}^{-1}$, scan range $m / z 100 \div 1000$ ).

\subsubsection{Typical Reaction Procedure}

To a solution of norfloxacin $(\mathbf{1}, 0.5 \mathrm{~g}, 1.56 \mathrm{mmol})$ and triethylamine $(0.5 \mathrm{~mL}, 3.6 \mathrm{mmol})$ in dichloromethane $(100 \mathrm{~mL})$, the suitable quinone $(2,3$ or $4,1.3 \mathrm{mmol})$ was added and the reaction mixture stirred at room temperature for $48 \mathrm{~h}$, monitoring by TLC (dichloromethane/methanol 95:5 $v / v$ and some drops of formic acid). The solvent was evaporated in vacuo and the residue was taken up with $1 \mathrm{M} \mathrm{HCl}$ aq.solution. The coloured suspension was filtered on a Büchner funnel and washed several times with $1 \mathrm{M} \mathrm{HCl}$ to remove triethylammonium salt and the unreacted norfloxacin. The resulting residue recovered on a filter was dried in essicator to obtain the corresponding pure compounds 5-7. 
7-(4-(3-Chloro-1,4-dioxo-1,4-dihydronaphthalen-2-yl)piperazin-1-yl)-1-ethyl-6-fluoro-4-oxo-1,4dihydroquinoline-3-carboxylic acid (5). TLC (dichloromethane/methanol = 95:5 $v / v$ with two drops of $\mathrm{HCOOH}): \mathrm{R}_{\mathrm{f}}=0.57$. Red-brown crystalline solid. Yield: $80 \%$. M.p.: $279^{\circ} \mathrm{C}$. IR: $2911 \mathrm{w}, 1721 \mathrm{~m}, 1672$ $\mathrm{m}, 1630 \mathrm{~m}, 1550 \mathrm{~m}, 1441 \mathrm{~m}, \mathrm{~cm}^{-1} .{ }^{1} \mathrm{H}$ NMR $\left(400 \mathrm{MHz}, \mathrm{CDCl}_{3}\right) \delta 8.69$ (s, 1H, H-2), 8.13 (m, 2H, Ar), 8.05 $\left(\mathrm{d}, 1 \mathrm{H}, J\left({ }^{1} \mathrm{H},{ }^{19} \mathrm{~F}\right)=7.8 \mathrm{~Hz}, \mathrm{Ar}\right), 7.72(\mathrm{~m}, 2 \mathrm{H}, \mathrm{Ar}), 6.89\left(\mathrm{~d}, 1 \mathrm{H}, J\left({ }^{1} \mathrm{H},{ }^{19} \mathrm{~F}\right)=6.6 \mathrm{~Hz}, 1 \mathrm{H}, \mathrm{H}-8\right), 4.34(\mathrm{q}, J=7.2$ $\mathrm{Hz}, 2 \mathrm{H}, \mathrm{N}-\underline{\mathrm{CH}_{2}}$ ), 3.82 (br t, $J=3.9 \mathrm{~Hz}, 4 \mathrm{H}, 2 \mathrm{H}-3^{\prime}$ and $2 \mathrm{H}-5^{\prime}$ ), 3.49 (br t, $J=4.6 \mathrm{~Hz}, 4 \mathrm{H}, 2 \mathrm{H}-2^{\prime}$ and $2 \mathrm{H}-6^{\prime}$ ), $1.60\left(\mathrm{t}, J=7.2 \mathrm{~Hz}, 3 \mathrm{H}, \mathrm{CH}_{3}\right)$. ESI(-)-MS: $m / z$ 508/510 [M-H] ${ }^{-}$.

7-(4-(3-Chloro-5,8-dihydroxy-1,4-dioxo-1,4-dihydronaphthalen-2-yl)piperazin-1-yl)-1-ethyl-6-fluoro-4oxo-1,4-dihydroquinoline-3-carboxylic acid (6). TLC $\left(\mathrm{CH}_{2} \mathrm{Cl}_{2} / \mathrm{MeOH}=95: 5 \mathrm{v} / \mathrm{v}\right.$, with two drops of $\mathrm{HCOOH}): \mathrm{R}_{\mathrm{f}}=0.51$. Dark violet crystalline solid. Yield: $70 \%$. M.p.: $276^{\circ} \mathrm{C}$. IR: $3456 \mathrm{~s}, 2930 \mathrm{w}, 1712 \mathrm{~m}$, $1610 \mathrm{~m}, 1444 \mathrm{~s}, \mathrm{~cm}^{-1} .{ }^{1} \mathrm{H}-\mathrm{NMR}\left(400 \mathrm{MHz}, \mathrm{CDCl}_{3}\right): \delta 12.68(\mathrm{~s}, 1 \mathrm{H}, \mathrm{OH}), 12.35(\mathrm{~s}, 1 \mathrm{H}, \mathrm{OH}), 8.70(\mathrm{~s}, 1 \mathrm{H}$, $\mathrm{H}-2), 8.14\left(\mathrm{~d}, 1 \mathrm{H}, J\left({ }^{1} \mathrm{H},{ }^{19} \mathrm{~F}\right)=13 \mathrm{~Hz}, \mathrm{H}-5\right), 6.88(\mathrm{~m}, 1 \mathrm{H}, \mathrm{H}-8), 7.33\left(\mathrm{~m}, 2 \mathrm{H}, \mathrm{H}-44^{\prime \prime}\right.$ and $\left.\mathrm{H}-5^{\prime \prime}\right), 4.32(\mathrm{q}, J=$ $\left.7.2 \mathrm{~Hz}, 2 \mathrm{H}, \mathrm{N}-\underline{\mathrm{CH}_{2}}\right), 3.84\left(\mathrm{br} \mathrm{t}, J=3.9 \mathrm{~Hz}, 4 \mathrm{H}, 2 \mathrm{H}-3^{\prime}\right.$ and $\left.2 \mathrm{H}-5^{\prime}\right), 3.53\left(\mathrm{brt}, J=4.6 \mathrm{~Hz}, 4 \mathrm{H}, 2 \mathrm{H}-2^{\prime}\right.$ and $2 \mathrm{H}-$ $\left.6^{\prime}\right), 1.61\left(\mathrm{t}, J=7.2 \mathrm{~Hz}, 3 \mathrm{H}, \mathrm{CH}_{3}\right)$. ESI(-)-MS: $m / z$ 540/542 [M-H]-.

7-(4-(6-Chloro-5,8-dioxo-5,8-dihydroquinolin-7-yl)piperazin-1-yl)-1-ethyl-6-fluoro-4-oxo-1,4dihydroquinoline-3-carboxylic acid (7a) and 7-(4-(7-chloro-5,8-dioxo-5,8-dihydroquinolin-6-yl)piperazin-1yl)-1-ethyl-6-fluoro-4-oxo-1,4-dihydroquinoline-3-carboxylic acid (7b), in 7:3 ratio, respectively. TLC (dichloromethane/methanol $=95: 5 v / v$ with two drops of $\mathrm{HCOOH}$ ): $\mathrm{R}_{\mathrm{f}}=0.40$. Light orange solid. Yield: 87\%. IR: $2908 \mathrm{w}, 1717 \mathrm{~m}, 1629 \mathrm{~m}, 1550 \mathrm{~m}, 1440 \mathrm{~m} \mathrm{~cm}^{-1} .{ }^{1} \mathrm{H}-\mathrm{NMR}\left(400 \mathrm{MHz}, \mathrm{CDCl}_{3}\right): \delta 8.99$ (d, J $\left.=4.4 \mathrm{~Hz}, 1 \mathrm{H}, \mathrm{H}-6^{\prime \prime}\right), 8.70(\mathrm{~s}, 1 \mathrm{H}, \mathrm{H}-2), 8.48\left(\mathrm{~d}, J=7.8 \mathrm{~Hz}, 1 \mathrm{H}, \mathrm{H}-4{ }^{\prime \prime}\right), 8.13\left(\mathrm{~d}, 1 \mathrm{H}, J\left({ }^{1} \mathrm{H},{ }^{19} \mathrm{~F}\right)=13 \mathrm{~Hz}, \mathrm{H}-5\right)$, $7.68\left(\mathrm{dd}, J=7.8,4.9 \mathrm{~Hz}, 1 \mathrm{H}, \mathrm{H}-5^{\prime \prime}\right), 6.90\left(\mathrm{~d}, 1 \mathrm{H}, J\left({ }^{1} \mathrm{H},{ }^{19} \mathrm{~F}\right)=6.6 \mathrm{~Hz}, 1 \mathrm{H}, \mathrm{H}-8\right), 4.34(\mathrm{q}, J=7.2 \mathrm{~Hz}, 2 \mathrm{H}, \mathrm{N}-$ $\left.\underline{\mathrm{CH}_{2}}\right), 3.88\left(\mathrm{br} \mathrm{t}, J=3.9 \mathrm{~Hz}, 4 \mathrm{H}, 2 \mathrm{H}-3^{\prime}\right.$ and $\left.2 \mathrm{H}-5^{\prime}\right), 3.51\left(\mathrm{br} \mathrm{t}, J=4.2 \mathrm{~Hz}, 4 \mathrm{H}, 2 \mathrm{H}-2^{\prime}\right.$ and $\left.2 \mathrm{H}-6^{\prime}\right), 1.61(\mathrm{t}, J=$ $\left.7.2 \mathrm{~Hz}, 3 \mathrm{H}, \mathrm{CH}_{3}\right)$. Significant HMBC correlations: 8.70 with $177.1(\mathrm{C}-4), 166.6(\mathrm{COOH}), 49.7 \mathrm{ppm}$ $\left(\mathrm{NCH}_{2}\right), 8.13$ with 177.1 (C-4), 6.9 with 121.3 ppm (C-4a), 3.51 with $51.1 \mathrm{ppm}\left(\mathrm{C}-3^{\prime}\right.$ and $\left.\mathrm{C}-5^{\prime}\right), 1.6$ with 49.7 ppm ( $\left.\mathrm{NCH}_{2}\right)$. ESI(-)-MS: $m / z$ 509/511 [M-H]-'.

\subsubsection{Preparation of 5-7 Sodium Salts}

A stoichiometric amount of sodium hydrogen carbonate was added to $5 \mathrm{mg}$ of each compound 5-7 suspended in methanol and the mixture was refluxed for $1 \mathrm{~h}$; solvent was removed in vacuo, obtaining the products in quantitative yield.

\subsection{Biological Evaluation}

Antimicrobial activity was evaluated by standard Kirby Bauer method on Gram-(+) bacteria Staphylococcus aureus (ATCC 6538) and Staphylococcus epidermidis (ATCC 12228) (Figure 3), on Gram (-) bacteria Escherichia coli (ATCC 25922) and on the yeast Saccharomyces cerevisiae used as fungal model.

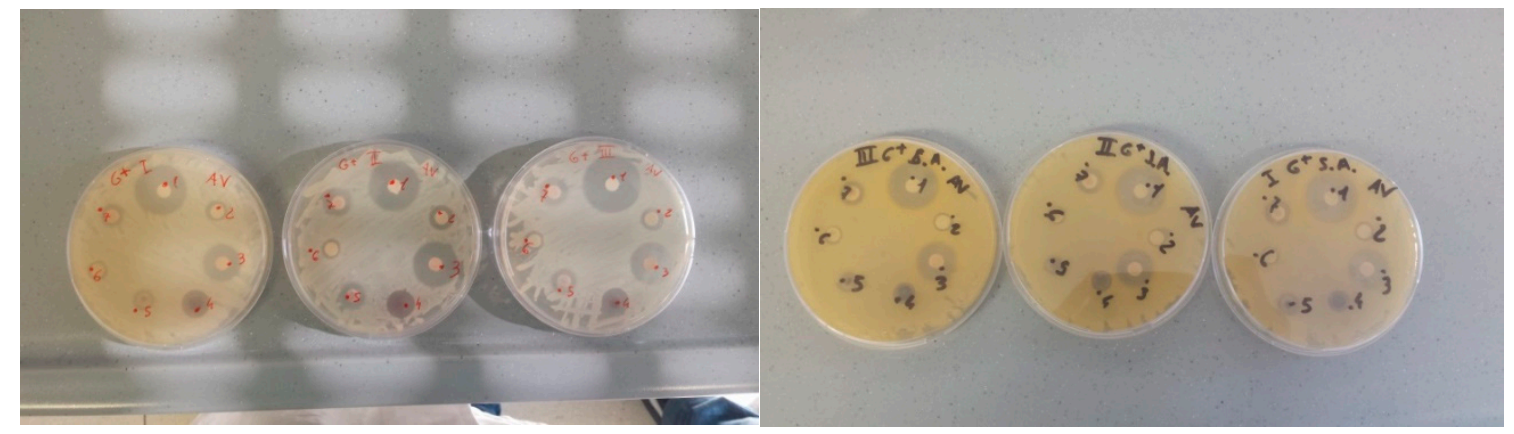

Figure 3. Results by in vitro antibacterial test on Staphylococcus epidermidis (left) and on Staphylococcus aureus (right). 


\subsection{Molecular Docking Calculation}

Calculations were carried out on a PC running at $3.4 \mathrm{GHz}$ on an Intel 172600 quad core processor with 8 GB RAM and 1 TB hard disk with Windows 7 Home Premium 64-bit SP1 as an operating system. Ligands were built and minimized using MMX force field by PC Model version 6.0 (Serena Software, Bloomington, IN, USA). The minimized molecules were saved in pdb extension. AutoDock Tools (ADT) package version 1.5.6rc3 was employed to generate the docking input files and to analyze docking results, whereas Autodock Vina 1.1.2 [16] was taken for docking calculation. The structures of Staphylococcus aureus (strain N315) DNA-gyrase (PDB ID: 5CDQ) was determined by Xray crystallography with a resolution of $2.95 \AA$. The structures were modified as follows: the moxifloxacin used as ligand and all the crystallization water molecules were removed saving the file in pdb extension. All hydrogen atoms were added by AutoDock Tools (ADT) and Gasteiger-Marsili charges were calculated saving the resulting file in pdbqt extension. Rotatable bonds were defined for each minimized ligand molecule. For the docking calculation a grid box of $20 \times 20 \times 20 \AA$ in $x, y$, $\mathrm{z}$ directions was created, spacing of $1.00 \AA$ and centered at $\mathrm{x}=42.527 \mathrm{y}=-46.679, \mathrm{z}=65.559$. Vina parameters were set as follows: exhaustiveness of the local search $=8$ and number of conformations to calculate $=10$. Results are expressed as energy associated to each ligand-enzyme complex in terms of Gibbs free energy values. The visual ligand-enzyme interactions were displayed using Discovery Studio Visualizer v.19.1.0.18287 [17].

\section{Conclusions}

New hybrid molecules containing different quinone units covalently linked to norfloxacin structure were synthesized and structurally characterized. Their antibacterial and antifungal activities were evaluated, in comparison with the starting molecules. Typical antifungal activity of quinones was not found for the hybrid molecules, whereas antibacterial effects resulted similar to norfloxacin. The most interesting $S$. aureus growth inhibition observed for the (7:3) mixture of $7 \mathbf{a} / \mathbf{7} \mathbf{b}$ was supported by data from docking calculation on S. aureus DNA-gyrase. The docking evidence of $7 \mathrm{a}$ and $\mathbf{6}$ interacting in a different region than moxifloxacin and norfloxacin, is interesting because associated to their best growth inhibition of S. aureus in the series of hybrid molecules investigated. These preliminary results are promising to find new agents overcoming the known quinolone resistance.

Funding: This research received no external funding

Acknowledgments: The authors thank Sabrina Pegoretti, Fernando Pezza, Fiorenzo Fedel and Chiara Mosele, Istituto Tecnico Tecnologico Buonarroti in Trento for technical support.

\section{References}

1. Defant: A.; Mancini, I. Design, synthesis and cancer cell growth inhibition evaluation of new aminoquinone hybrid molecules. Molecules 2019, 24, 2224, doi:10.3390/molecules24122224.

2. Klahn, P.; Broenstrup, M. Bifunctional antimicrobial conjugates and hybrid antimicrobials. Nat. Prod. Rep. 2017, 34, 832-885, doi:10.1039/C7NP00006E.

3. Gupta, V.; Datta, P. Next-generation strategy for treating drug resistant bacteria: Antibiotic hybrids. Indian J. Med. Res. 2019, 149, 97-106, doi:10.4103/ijmr.IJMR_755_18.

4. Ravichandiran, P.; Sheet, S.; Premnath, D.; Kim, A.R.; Yoo, D.J. 1,4-Naphthoquinone analogues: Potent antibacterial agents and mode of action evaluation. Molecules 2019, 24, 1437, doi:10.3390/molecules24071437.

5. Sakaki, K.; Abe, H.; Yoshizak, F. In vitro antifungal activity of naphthoquinone derivatives. Biol. Pharm. Bull. 2002, 25, 669-670, doi:10.1248/bpb.25.669.

6. Patil, S.J.; Pingle, A.P.; Tamboli, K. Design, synthesis and evaluation of novel substituted fluoroquinolonebenzimidazole antibacterials. World J. Pharm. Res. 2014, 3, 596-615.

7. Meltem Yolal, M.; Hacer, B.; Yildiz, U.; Arif, M.; Serdar, U.; Alpay, K.S.; Neslihan, D. Microwave assisted synthesis of some hybrid molecules derived from norfloxacin and investigation of their biological activities. Eur. J. Med. Chem. 2013, 67, 230-242, doi:10.1016/j.ejmech.2013.06.045. 
8. Reis, W.J.; Bozzi, I.A.O.; Ribeiro, M.F.; Halicki, P.C.B.; Ferreira, L.A.; da Silva, P.E.A.; Ramos, D.F.; de Simone, C.A.; da Silva, E.N., Jr. Design of hybrid molecules as antimycobacterial compounds: Synthesis of isoniazid-naphthoquinone derivatives and their activity against susceptible and resistant strains of Mycobacterium tuberculosis. Bioorg. Med. Chem. 2019, 27, 4143-4150, doi:10.1016/j.bmc.2019.07.045.

9. Bala, B.D.; Muthusaravanan, S.; Choon, T.S.; Ali, M.A.; Perumal, S. Sequential synthesis of amino-1,4naphthoquinone-appended triazoles and triazole-chromene hybrids and their antimycobacterial evaluation. Eur. J. Med. Chem. 2014, 85, 737-746, doi:10.1016/j.ejmech.2014.08.009.

10. Muge, G.; Yahya, N.; Ergin, K.; Burcu, A.; Nurgul, S.; Mahmut, U.; Ertan, S.; Selma, E.; Zeynel, S. Novel highly functionalized 1,4-naphthoquinone 2-iminothiazole hybrids: Synthesis, photophysical properties, crystal structure, DFT studies, and anti(myco)bacterial/antifungal activity. J. Mol. Str. 2019, 1196, 536-546, doi:10.1016/j.molstruc.2019.06.087.

11. Tangeti, V.S.; Reddy, B.H.; Sombabu, P.A. Facile synthesis and pharmacological evolution of pyranopyrazole-naphthoquinone hybrids as antimicrobial and anticancer agents. Pharma Chem. 2017, 9, 111.

12. Defant, A.; Guella, G.; Mancini, I. Synthesis and in vitro cytotoxicity evaluation of novel naphthindolizinedione derivatives. Arch. Pharm. Chem. Life Sci. 2007, 340, 147-153, doi:10.1002/ardp.200600160.

13. Defant, A.; Guella, G.; Mancini, I. Synthesis and in vitro cytotoxicity evaluation of novel naphtindolizinedione derivatives, part II: Improved activity for aza-analogues. Arch. Pharm. Chem. Life Sci. 2009, 342, 80-86, doi:10.1002/ardp.200800177.

14. Defant, A.; Guella, G.; Mancini, I. Regioselectivity in the multi-component synthesis of indolizinoquinoline5,12-dione derivatives. Eur. J. Org. Chem. 2006, 2006, 4201-4210, doi:10.1002/ejoc.200600317.

15. Defant, A.; Rossi, B.; Viliani, G.; Guella, G.; Mancini, I. Metal-assisted regioselectivity in nucleophilic substitutions: A study by Raman spectroscopy and density functional theory calculations. J. Raman Spectrosc. 2010, 41, 1398-1403, doi:10.1002/jrs.2631.

16. Trott, O.; Olson, A.J. AutoDock Vina: Improving the speed and accuracy of docking with a new scoring function, efficient optimization, and multithreading. J. Comp. Chem. 2010, 31, 455-461, doi:10.1002/jcc.21334.

17. Dassault Systèmes BIOVIA. Discovery Studio Modeling Environment, Release 2019; Dassault Systèmes: San Diego, CA, USA, 2019.

(C) 2019 by the authors. Licensee MDPI, Basel, Switzerland. This article is an open access article distributed under the terms and conditions of the Creative Commons Attribution (CC BY) license (http://creativecommons.org/licenses/by/4.0/). 